\title{
Heritabilities for antler characteristics and body weight in yearling white-tailed deer
}

\author{
JOHN D. WILLIAMS*†, W. F. KRUEGER \& \& DONNIE H. HARMEL§ \\ tDepartment of Veterinary Pathobiology and Texas Agricultural Experiment Station, 市Department of Poultry Science, \\ College of Agriculture and Life Sciences, Texas A \& M University, College Station, TX 77843 and \$Texas Parks and \\ Wildlife Department, Kerr Wildlife Management Area, Hunt, TX 78024, U.S.A.
}

\begin{abstract}
Heritabilities for two body weights and five antler characteristics were estimated for a captive white-tailed deer (Odocoileus virginianus) herd maintained by the Texas Parks and Wildlife Department. Single male breeding pens with 10-14 female deer were used for five consecutive generations. To minimize selection and maintain a broad genetic base, different sets of sires and as many different dams as possible were randomly assigned as breeders each generation. All deer were accurately predigreed by sire and dam and, except for birth weight, traits were measured at 1.5 years of age. Heritabilities were estimated utilizing (1) sire and within-sire components of variance, and (2) regression of male progeny performance on sire performance. Theoretically, these procedures estimate the amount of additive genetic variance present in a population without indication of non-additive genetic (dominance and epistasis) and maternal effects. Heritabilities ranged from $0.00-0.17$ (birth weight), 0.58-0.64 (body weight), $0.22-0.56$ (antler points), $0.47-0.70$ (main beam length), 0.03-0.43 (antler spread), $0.80-0.89$ (basal circumference) and 0.71-0.86 (antler weight). These heritabilities, except for birth weight, suggest that substantial genetic change could be expected from individual selection if realistic selection differentials were used.
\end{abstract}

Keywords: antlers, body weight, genetic variance, heritability, white-tailed deer.

\section{Introduction}

Heritability of antler characteristics and body weight in white-tailed deer (Odocoileus virginianus) is not well documented. Harmel et al. (1989) reported that the heritabilities of body weight, main beam length, antler weight, basal circumference of antlers, antler spread and total antler points were relatively high for 2.5 and 3.5 -year-old white-tailed deer. These heritability estimates, however, were based on small numbers of sires and male progeny per sire.

Scribner et al. (1984) simulated several selective removal strategies for spike bucks using arbitrary heritabilities and selection differentials and concluded that body weight and antler development are quantitative traits influenced by polygenic inheritance. According to Breshears et al. (1988), white-tailed deer have a high level of heterozygosity and more alleles per locus on the average than do other mammals. They also estimated genetic variability at 36 loci using horizontal

*Correspondence: Department of Veterinary Pathobiology, College of Veterinary Medicine, Texas A \& M University, College Station, TX 77843, U.S.A. starch gel electrophoresis techniques. Smith et al. (1987) reported that deer with higher heterozygosities exhibit significantly greater size for five antler characteristics and greater antler symmetry.

Templeton et al. (1982) reported that a single gene in the genome of white-tailed deer had a major effect on the number of antler points at 2.5 years of age. They hypothesized that the presence of a dominant allele in the genotype resulted in six to 10 antler point phenotypes, while the recessive allele in the genotype produced two to five antler point phenotypes. Williams \& Harmel (1984) presented evidence that bucks with less than six antler points at 1.5 years of age are genetically inferior for both quality of antlers and body weight, and that there was a positive phenotypic correlation between these two characteristics.

The objective of this study was to obtain heritability estimates for two body weights and five antler characteristics in white-tailed deer. All heritability estimates, except birth weight, were calculated from data collected from male white-tailed deer at 1.5 years of age. This appears to be an optimal age to evaluate the breeding value of white-tailed deer (Williams \& Harmel, 1984). 


\section{Methods}

Male white-tailed deer with known antler and body weight measurements taken at 1.5 years of age were used as breeders and, depending upon the availability of dams, five to six single male breeding pens were used each year. Ten to 14 dams were placed in each breeding pen to ensure that a reasonable number of male progeny would be produced by each sire. The female breeders were maintained as a group in their respective pens until fawns were born. Since the breeding pens consisted of six adjacent 0.27 ha enclosures surrounded by a $2.44 \mathrm{~m}$ chain link fence, there should have been little pen effect which would appear as a genetic effect.

Males and females were randomly selected from a pedigree population maintained at the Kerr Wildlife Management Area, Hunt, Texas. Different sires were used in breeding pens in each of five consecutive breeding seasons to minimize selection and to maintain a broad genetic base among male breeders. Breeding females were assigned to single male pens at random to simulate random mating as much as possible. Because of a shortage of females, the same female breeders often were used for two or more breeding seasons. Also, since the sires were used for only one breeding season, the dams were not mated to the same sire if they were used in more than one year.

At birth, offspring were ear-tagged and tattooed, and birth weight (BW) was collected upon verifying the dam. Although it is common for white-tailed deer to allow fawns other than their own to nurse, the females were watched very closely during the fawning season and all fawns were assigned to a dam within $24 \mathrm{~h}$ of birth. This procedure of carefully observing both the dams and fawns on a daily basis leads to increased confidence in the accuracy of fawn pedigree. In a companion project, DNA fingerprinting has not uncovered any error in pedigree assignment (unpublished data).

All dams and fawns were moved from the breeding pens to a 1.62 ha pen at birth where they were maintained as a group until weaning. Progeny were reared to 1.5 years of age at which time body weight (WT) and antler measurements were taken. All antlers were removed $1-2 \mathrm{~cm}$ above the base, permanently marked and stored for future evaluation. Antler measurements taken included number of antler points (PT) over 25 $\mathrm{mm}$ in length, maximum inside spread (SP) of main beam, basal circumference $(\mathrm{BC})$ of main beam, main beam (MB) length and total antler weight (AW). Birth weight (BW) and WT were measured in kilograms; SP, $\mathrm{MB}$, and $\mathrm{BC}$ in millimetres; and $\mathrm{AW}$ in grams.

All fawns were weaned at 4-6 months of age, placed in a 1.62 ha pen, and fed ad libitum for the remainder of the study. The feed used was a pelleted 16 per cent protein diet containing recommended levels of minerals and vitamins (Verme \& Ullrey, 1972). All sires, dams and progeny received the same 16 per cent protein dietary formulation ad libitum during the study and the same facilities were used each year.

\section{Statistical methods used to estimate heritability}

Heritabilities were estimated utilizing three different statistical methods. Since all sires and some of the dams were replaced each year, the year to year variation would be confounded with genetic differences among annual breeder replacements. Therefore, year and pen differences for each of the traits were assumed to be random with mean zero and not included in any of the models used to estimate heritability. All statistical analyses were performed with the aid of the STATISTICAL ANALYSIS SYSTEM (SAS, 1985).

\section{Method 1}

The first method utilized hierarchical analysis of variance where sire $\left(v_{S}^{2}\right)$ and within sire $\left(v_{\mathrm{E}}^{2}\right)$ components of variance were estimated. The statistical model utilized was

$Y_{i k}=\mu+s_{i}+e_{i k}$,

where $Y_{i k}$ is a measurement from the $i k$ th offspring, $\mu$ the population mean, $s_{i}$ the effect of the $i$ th sire, and $e_{i k}$ the uncontrolled environmental and genetic deviations attributable to individuals within sire groups. All effects were assumed to be random, normal and independent with expectations equal to zero (Becker, 1984).

Heritability was estimated using the equation

$h_{\mathrm{S}}^{2}=4 v_{\mathrm{S}}^{2} /\left(v_{\mathrm{S}}^{2}+v_{\mathrm{E}}^{2}\right)$.

The variance component $v_{S}^{2}$ theoretically contains $1 / 4$ of the additive $(A)$ genetic variance plus $1 / 16$ of the additive $x$ additive $(A A)$ genetic variance and $1 / 64$ of the $A A A$ genetic variance (Lerner, 1958; Falconer, 1960). The $A A$ and $A A A$ type interactions represent epistatic effects of additive gene loci which contribute to the additive genetic variance.

\section{Method 2}

The second method of estimating heritability utilized regression of mean performance of male progeny $(\mathrm{O})$ on sire $(S)$ performance. The statistical model was

$Z_{i}=b_{\mathrm{OS}} X_{i}+e_{i}$, 
where $Z_{i}$ is the mean of all male offspring for the $i$ th sire, $X_{i}$ is the observation on the $i$ th sire, $b_{\mathrm{OS}}$ is the regression of $Z$ on $X$, and $e_{i}$ is the error associated with the $Z$ s (Becker, 1984). The resulting estimate of heritability is derived from the equation

$h^{2}=2 b_{\mathrm{OS}}$.

\section{Method 3}

This method was a modification of method 2 and regressed individual performance of male progeny on the record of the sire to yield another estimate of heritability. Although the regression of offspring on parent estimate of heritability is derived differently than the variance component method, both methods 2 and 3 estimate all of the additive $(A)$ genetic variance and a portion of the epistatic effect $(A A$ and $A A A$ interaction) of additive genes interacting with additive

Table 1 Total white-tailed deer sires and dams used as breeders and progeny surviving to 1.5 years of age for each of five generations

\begin{tabular}{lcccc}
\hline & & & \multicolumn{2}{c}{ Total progeny } \\
\cline { 4 - 5 } Year & $\begin{array}{c}\text { Total } \\
\text { sires }\end{array}$ & $\begin{array}{c}\text { Total } \\
\text { dams }\end{array}$ & Males & Females \\
\hline 1986 & 6 & 30 & 40 & 31 \\
1987 & 6 & 15 & 19 & 8 \\
1988 & 6 & 26 & 22 & 29 \\
1989 & 5 & 32 & 38 & 34 \\
1990 & 5 & 24 & 27 & 27 \\
Total & 28 & $127^{*}$ & 146 & 129 \\
\hline
\end{tabular}

*A total of 78 different females were used as breeders; however, some were used in two or more breeding seasons. genes and contributing to the additive genetic variance influencing a trait in the population. Neither method gives an estimate of dominance, non-additive epistatic effect, or maternal effect.

\section{Results}

The total sires and dams producing offspring in each of the five generations as well as the total male and female progeny reaching 1.5 years of age are shown in Table 1 . In 1987, dam and progeny mortality was high because of extremely wet weather conditions resulting in health problems.

Yearly mean performance values for each of the seven traits from male progeny are presented in Table 2. Similarly, the mean values for the corresponding traits in the sires are presented in Table 3. The annual sire means for each of the traits varied considerably from year to year (Table 3) and, although no selection was intended for the sires in the breeding pens, their individual and cumulative mean peformance for each of the traits at 1.5 years of age exceeded that of their male progeny at the same age. The pooled within-year standard deviations and corresponding coefficients of variation for each of these means are large (Table 4). Part of this variation may be the result of the limited number of sires used as breeders each year.

With the exception of birth weight $(0.17)$, antler points $(0.22)$ and antler spread $(0.03)$, the heritabilities estimated from variance component analysis (method 1) are considered high (Table 5). When confidence limits are placed around the estimates for WT, MB, BC and $\mathrm{AW}$, the lower limits are positive $(P<0.05)$. When regression of individual progeny performance and mean progeny performance on sire performance are

Table 2 Mean values of five antler measurements at 1.5 years and two body weights for white-tailed deer male progeny for five consecutive years

\begin{tabular}{|c|c|c|c|c|c|}
\hline \multirow[b]{2}{*}{ Trait } & \multicolumn{5}{|c|}{ Progeny means by years } \\
\hline & $\begin{array}{l}1986 \\
(40)^{*}\end{array}$ & $\begin{array}{l}1987 \\
(19)\end{array}$ & $\begin{array}{l}1988 \\
(22)\end{array}$ & $\begin{array}{l}1989 \\
(38)\end{array}$ & $\begin{array}{c}1990 \\
(27)\end{array}$ \\
\hline Birth weight (kg) & 2.50 & 2.90 & 2.75 & 2.77 & 2.45 \\
\hline $\begin{array}{l}\text { Body weight }(\mathrm{kg}) \\
(1.5 \text { years })\end{array}$ & 47.10 & 52.63 & 49.75 & 53.48 & 52.17 \\
\hline Antler points & 5.03 & 6.22 & 5.45 & 5.92 & 6.26 \\
\hline Main beam length $(\mathrm{mm})$ & 235.78 & 264.31 & 248.43 & 261.42 & 298.72 \\
\hline $\operatorname{Spread}(\mathrm{mm})$ & 204.33 & 221.44 & 207.18 & 231.68 & 239.07 \\
\hline $\begin{array}{l}\text { Basal circumference } \\
(\mathbf{m m})\end{array}$ & 61.13 & 70.22 & 61.98 & 69.24 & 72.31 \\
\hline Antler weight (g) & 158.54 & 242.87 & 179.92 & 228.90 & 280.47 \\
\hline
\end{tabular}

*Number of male progeny reaching 1.5 years of age. 
Table 3 Mean values of five antler measurements at 1.5 years and two body weights of sires for five consecutive years

\begin{tabular}{lrrrrr}
\hline & \multicolumn{5}{c}{ Means by years } \\
\cline { 2 - 6 } & $\begin{array}{c}1986 \\
\text { Trait }\end{array}$ & $\begin{array}{c}1987 \\
(6)\end{array}$ & $\begin{array}{c}1988 \\
(6)\end{array}$ & $\begin{array}{c}1989 \\
(5)\end{array}$ & $\begin{array}{c}1990 \\
(5)\end{array}$ \\
\hline Birth weight $(\mathrm{kg})$ & 3.1 & 2.3 & 2.4 & 3.2 & 2.5 \\
Body weight $(\mathrm{kg})$ & 52.0 & 59.5 & 50.0 & 57.5 & 56.3 \\
$\quad(1.5$ years) & 5.3 & 7.6 & 6.0 & 7.4 & 7.2 \\
Antler points & 222.1 & 301.8 & 268.9 & 299.9 & 328.8 \\
Main beam length (mm) & 220.5 & 291.6 & 222.5 & 262.0 & 273.8 \\
Spread (mm) & 63.9 & 81.6 & 63.5 & 74.0 & 73.3 \\
Basal circumference & $(\mathrm{mm})$ & & & & \\
Antler weight (g) & 196.5 & 372.6 & 197.1 & 299.2 & 304.4 \\
\hline
\end{tabular}

*Number of sires utilized in breeding pens in each of the five years. Data were collected at birth and 1.5 years of age.

Table 4 Means, standard deviations $(\mathrm{SD})$ and coefficients of variation $(\mathrm{CV}, \%)$ for five antler measurements at 1.5 years and two body weights for white-tailed deer sires and progeny pooled for five consecutive years*

\begin{tabular}{|c|c|c|c|c|c|c|}
\hline & \multicolumn{3}{|c|}{ Sires } & \multicolumn{3}{|c|}{ Progeny } \\
\hline & Mean & SD & $\mathrm{CV}(\%)$ & Mean & SD & $\mathrm{CV}(\%)$ \\
\hline Birth weight $(\mathrm{kg})$ & 2.69 & 0.51 & 19.16 & 2.64 & 0.47 & 17.65 \\
\hline $\begin{array}{l}\text { Body weight }(\mathrm{kg}) \\
(1.5 \text { years })\end{array}$ & 54.52 & 7.08 & 12.99 & 50.71 & 5.55 & 10.95 \\
\hline Antler points & 6.63 & 1.91 & 28.86 & 5.72 & 1.93 & 33.79 \\
\hline Main beam length $(\mathrm{mm})$ & 281.91 & 61.94 & 21.97 & 259.84 & 67.56 & 26.00 \\
\hline $\operatorname{Spread}(\mathrm{mm})$ & 251.67 & 52.79 & 20.98 & 220.67 & 61.47 & 27.86 \\
\hline $\begin{array}{l}\text { Basal circumference } \\
(\mathrm{mm})\end{array}$ & 70.57 & 10.15 & 14.38 & 66.60 & 8.96 & 13.45 \\
\hline Antler weight $(\mathrm{g})$ & 268.23 & 103.60 & 38.62 & 213.61 & 104.54 & 48.94 \\
\hline
\end{tabular}

*Standard deviations and coefficients of variation are pooled within years.

used to estimate heritability (methods 2 and 3), all estimates, except birth weight, are high. Placing confidence limits around these estimates also suggests that the lower limits would be strongly positive $(P<0.05)$. It is postulated that birth weight, at least in this population, is under strong maternal and environmental influence. Because of cost and facility limitations the experimental design could not be extended to obtain a valid estimate of maternal influences; however, rough computations, not reported here, suggest that significant maternal and environmental effects contribute to the variance for birth weight with resultant low heritability.

\section{Discussion}

Smith et al. (1976, 1982), Scribner et al. (1984), Chesser \& Smith (1987) and Breshears (1988) recognized that body weight and antler characteristics were moderately to highly heritable, but did not determine heritabilities. Harmel et al. (1989), using data collected from 1973 to 1985, reported heritabilities for length of main beam, antler weight and basal circumference in 1.5-year-old deer of $0.80,1.41$ and 0.63 respectively. Estimates presented in this study, from a different data set, were 0.47-0.70 (MB), 0.71-0.86 (AW) and 0.72-0.89 (BC). Harmel et al. (1989) also reported heritabilities for birth weight, main beam length, antler weight, basal circumference, antler spread and antler 
Table 5 The heritabilities $\left(h^{2}\right)$, standard errors (SE) and lower confidence limits, for five antler measurements, birth weight and 1.5 -year-old body weight in whitetailed deer

\begin{tabular}{|c|c|c|c|c|c|c|}
\hline \multirow{4}{*}{$\begin{array}{l}\text { Traits } \\
\text { Birth weight }\end{array}$} & \multicolumn{6}{|c|}{ Heritabilities and standard errors } \\
\hline & \multirow{2}{*}{\multicolumn{2}{|c|}{$\begin{array}{c}\text { Variance } \\
\text { component } \\
\text { analysis } \\
\left(h_{\mathrm{S}}^{2}\right)(\mathrm{SE}) \\
(\text { method } 1)\end{array}$}} & \multicolumn{4}{|c|}{ Regression of offspring on sires } \\
\hline & & & \multicolumn{2}{|c|}{$\begin{array}{c}\text { Family means } \\
\left(h^{2}\right) \quad(\mathrm{SE}) \\
(\operatorname{method} 2)\end{array}$} & \multicolumn{2}{|c|}{$\begin{array}{l}\text { All progeny } \\
\left(h^{2}\right) \quad(\mathrm{SE}) \\
(\operatorname{method} 3)\end{array}$} \\
\hline & 0.17 & 0.26 & 0.04 & 0.16 & -0.13 & 0.16 \\
\hline $\begin{array}{l}\text { Body weight } \\
(1.5 \text { years })\end{array}$ & $0.64^{*}$ & 0.33 & $0.58 *$ & 0.14 & $0.59^{*}$ & 0.12 \\
\hline Points & 0.22 & 0.23 & $0.56^{*}$ & 0.20 & $0.46^{*}$ & 0.14 \\
\hline Main beam length & 0.49 & 0.34 & $0.70^{*}$ & 0.22 & $0.47^{*}$ & 0.14 \\
\hline Spread & 0.03 & 0.24 & $0.43^{*}$ & 0.18 & $0.42 *$ & 0.16 \\
\hline $\begin{array}{l}\text { Basal } \\
\quad \text { circumference }\end{array}$ & $0.80^{*}$ & 0.35 & $0.89^{*}$ & 0.16 & $0.72^{*}$ & 0.12 \\
\hline Antler weight & $0.71^{*}$ & 0.34 & $0.86^{*}$ & 0.18 & $0.75^{*}$ & 0.14 \\
\hline
\end{tabular}

points of 2.5 and 3.5-year-old male deer which were similar to those in Table 5. Therefore, age of deer may not be a significant factor when estimating heritabilities for white-tailed deer. Five antler traits $(\mathrm{PT}, \mathrm{MB}, \mathrm{SP}$, $\mathrm{BC}, \mathrm{AW}$ ) and $\mathrm{WT}$ at 1.5 years in this study were classified as intermediate to highly heritable.

Additive variance is the variance of breeding value, and is an important component of variance since it is the chief cause of resemblance between relatives and of the response of the population to selection (Falconer, 1960). The effectiveness of individual selection to change a phenotypic trait is related to the amount of additive genetic variance present, or the size of the heritability. If non-additive genetic variance (dominance and epistasis) is important, more sophisticated breeding systems must be employed to take advantage of this source of genetic variation. We were unable to obtain estimates of dominance and epistatic effects because we were unable to obtain reliable sire $\times$ dam interaction mean squares. Templeton et al. (1982) reported a dominant allele with a major effect on phenotypic expression of from six to 10 antler points, and a simple recessive allele contributing to expression of from two to five points.

The heritability of birth weight in white-tailed deer is low and appears to follow a pattern observed in other mammals where maternal effects appear to influence significantly birth weight. Falconer $(1960)$ states that maternal effects are a frequent source of environmental differences between families, especially in mammals because the young are subjected to the maternal environment during the first stages of life. Johansson \& Rendel (1968) present evidence that maternal environment has a considerable influence on the birth weight of calves; however, differences resulting from maternal environment tend to decrease with rising levels of nutrition of the dam. Clutton-Brock et al. (1989) and Gomendio et al. (1990) have recognized the importance of maternal influence in red deer (Cervus elaphas L.) They note that such factors as the lactating ability of the mother, number of progeny produced, sex ratio of calves at birth and plane of nutrition not only affect the newly born calf, but the condition of the mother as well. Lerner (1958) lists several factors that induce maternal effects between dam families. These include cytoplasmic inheritance, maternally provided nutrition, passive transmission of either pathogens or of antibodies from dam to offspring and imitative behaviour. Falconer (1960) adds the age and size of dams to this list. From a selection point of view, heritability of birth weight in white-tailed deer appears to be a poor variable to use because it is subject to a large number of environmental factors that affect prenatal and postnatal development. One must conclude that birth weight in this population of white-tailed deer is not highly heritable $\left(h^{2}=0.00-0.17\right)$.

White-tailed deer are believed to possess a high level of heterozygosity (Smith et al., 1976; Breshears et al., 1988; Scribner et al., 1984, 1989; Scribner \& Smith, 1990). A review of papers by Carr et al., (1986), Derr 
(1991), Derr et al. (1991) and Ballinger et al. (1992) suggests considerable genetic variation in the genome of white-tailed deer populations. Scribner et al. (1984) used arbitrary selection differentials and heritabilities to model a population of white-tailed deer and reported that individual selection could be effective in altering the phenotypic characteristics of a population. They did not take into account the direction and magnitude of genetic correlations: In our study, the magnitudes of the heritabilities are large for all traits except $\mathrm{BW}$, indicating that there is considerable genotypic variability in this population. It would follow that there would be ample genetic variability for mass selection to be effective.

\section{Acknowledgements}

Sincere appreciation is expressed to G. W. Litton for his support and encouragement, to all the Kerr Wildlife Management Area staff, especially Joe Johnston, for day to day care of the deer, and to all those who assisted in the data collection process. This study was funded by the Texas Parks and Wildlife Department (Federal Aid Project W-109-R) and the Texas Agricultural Experiment Station (IP-6666).

\section{References}

BALLINGER, S. W., BLANKENSHIP, L. H., BICKHAM, J. W. AND CARR, S. M. 1992. Allozyme and mitochondrial DNA analysis of a hybrid zone between white-tailed and mule deer in West Texas. Biochem. Genet., 30, 1-11.

BECKER, w. A. 1984. Manual of Quantitative Genetics, 4th edn. Academic Enterprises, Pullman, WA.

BRESHEARS, D. D., SMITH, M. H., COTHRAN, E. G. AND JOHNS, P. E. 1988. Genetic variability in white-tailed deer. Heredity, 60, 139-146.

CARR, S. M., BALLINGER, S. W., DERR, J. N., BLANKENSHIP, L. H. AND BICKHAM, J. W. 1986. Mitochondrial DNA analysis of hybridization between sympatric white-tailed deer and mule deer in West Texas. Proc. Natl. Acad. Sci. U.S.A., 83, 9576-9580.

CHESSER, R. K. AND SMITH, M. H. 1987. Relationship of genetic variation to growth and reproduction in the white-tailed deer. In: Wemmer, C. (ed.) Biology and Management of the Cervidae, pp. 168-177. Smithsonian Institution Press, Washington, D.C.

CLUTTON-BROCK, T. H., ALBON, S. D. AND GUINNESS, F. E. 1989. Fitness costs of gestation and lactation in wild mammals. Nature, 337, 260-262.

DERR, J. N. 1991. Genetic interactions between white-tailed and mule deer in the Southwestern United States. J. Wildl. Management, 55, 228-237.
DERR, J. N., HALE, D. W., ELlSWORTH, D. L. AND BICKHAM, J. W. 1991. Fertility in an $F_{1}$ male hybrid of white-tailed deer $\times$ mule deer. J. Reprod. Fert., 93, 111-117.

FALCONER, D. S. 1960. Introduction to Quantitative Genetics. Ronald Press, New York.

GOMEND1O, M., CLUTTON-BROCK, T. H., ALBON, S. D., GUINNESS, F. E. AND SIMPSON, M. J. 1990. Mammalian sex ratios and variation in costs of rearing sons and daughters. Nature, 343, 261-263.

HARMEL, D. E., WILLIAMS, J. D. AND ARMSTRONG, w. E. 1989. Effects of genetics and nutrition on antler development and body size of white-tailed deer. Final Report, Texas Parks and Wildlife, Hunt, TX.

Johansson, 1. AND Rendel, J. 1968. Genetics and Animal Breeding. Freeman, San Francisco.

LERNER, 1. M. 1958. The Genetic Basis of Selection. Wiley, New York.

SAS INSTITUTE INC. 1985. SAS User's Guide: Statistics, version 5. SAS Institute, Cary, NC.

SCRIBNER, K. T. AND SMITH, M. H. 1990. Genetic variability and antler development. In: Bubenik, G. A. and Bubenik, A. B. (eds) Horns, Proghorns and Antlers, pp. 460-476. Springer, New York.

SCRIBNER, K. T., SMITH, M. H. AND JOHNS, P. E. 1984. Age, condition, and genetic effects on incidence of spike bucks. Proc. Annu. Conf. Southeast Assoc. Fish and Wildlife Agencies, 38, 23-32.

SCRIBNER, K. T., SMITH, M. H. AND JOHNS, P. E. 1989. Environmental and genetic components of antler growth in whitetailed deer. J. Mammal., 70, 284-291.

SMITH, M. H., CHESSER, R. K., COTHRAN, E. G. AND JOHNS, P. E. 1982. Genetic variability and antler growth in a natural population of white-tailed deer. In: Brown, R. D. (ed.) Antler Development in Cervidae, pp. 365-387. Caesar Kleberg Wildlife Research Institute, Kingsville, TX.

SMITH, M. H., HILLESTAD, H. O., MANLOVE, M. N. AND MARCHINGTON, R. L. 1976. Use of population genetics data for the management of fish and wildlife populations. Trans. North Am. Wildl. Nat. Resources Conf., 41, 119-133.

SMITH, M. H., SCRIBNER, K. T., RHODES, O. E., Jr. AND JOHNS, P. E. 1987. Genetics and antler development. Proc 18th Congr. Int. Union Game Biol., 1, 323-326. Swait Press, Krakow, Poland.

TEMPLETON, J. W., SHARP, R. M., WILliAMS, J. D., DAVIS, D. S., HARMEL, D. E., ARMSTrong, w. E. AND WARdroup, s. E. 1982. Single dominant major gene effect on the expression of antler point number in the white-tailed deer. In: Brown, R. D. (ed), Antler Development in Cervidae, p. 469. Caesar Kleberg Wildlife Research Institute, Kingsville, TX.

VERME, L. J. AND ULLREY, D. E. 1972. Feeding and nutrition of deer. In: The Digestive Physiology and Nutrition of Ruminants, vol. 3, Practical Nutrition, pp. 275-291. D.C. Church, Corvallis, OR.

WILLIAMS, J. D. AND HARMEL, D. E. 1984. Selection for antler points and body weight in white-tailed deer. Proc. Annu. Conf. Southeast Assoc. Fish and Wildlife Agencies, 38, 43-50. 